\title{
An overview on the treatment of postmenopausal osteoporosis
}

\author{
Uma visão geral sobre o tratamento da osteoporose pós-menopausa
}

Sergio Setsuo Maeda', Marise Lazaretti-Castro²

${ }^{1}$ Departamento de Ciências Fisiológicas, Faculdade de Ciências Médicas da Santa Casa de São Paulo (FCMSCSP), São Paulo, SP, Brazil

${ }^{2}$ Disciplina de Endocrinologia, Universidade Federal de São

Paulo, Escola Paulista de Medicina (Unifesp/EPM), São Paulo, SP, Brazil
Correspondence to: Sergio Setsuo Maeda Rua Conselheiro Furtado, 847, ap. 93 01511-001 - São Paulo, SP, Brazil ssetsuo@terra.com.br

Received on Oct/1/2013 Accepted on Nov/25/2013

\begin{abstract}
Osteoporosis is a worldwide health problem related to the aging of the population, and it is often underdiagnosed and undertreated. It is related to substantial morbidity, mortality and impairment of the quality of life. Estrogen deficiency is the major contributing factor to bone loss after menopause. The lifetime fracture risk at 50 years of age is about $50 \%$ in women. The aim of the treatment of osteoporosis is to prevent fractures. Non-pharmacological treatment involves a healthy diet, prevention of falls, and physical exercise programs. Pharmacological treatment includes calcium, vitamin $D$, and active medication for bone tissue such, as anti-resorptives (i.e., SERMs, hormonal replacement therapy, bisphosphonates, denosumab), bone formers (teriparatide), and mixed agents (strontium ranelate). Bisphosphonates (alendronate, risedronate, ibandronate, and zoledronate) are the most used anti-resorptive agents for the treatment of osteoporosis. Poor compliance, drug intolerance, and adverse effects can limit the benefits of the treatment. Based on the knowledge on bone cells signaling, novel drugs were developed and are being assessed in clinical trials. Arq Bras Endocrinol Metab. 2014;58(2):162-71

Keywords

Osteoporosis; treatment, post-menopause; anti-reabsorptives
\end{abstract}

\section{RESUMO}

A osteoporose é um problema de saúde mundial relacionada com o envelhecimento da população e muitas vezes é subdiagnosticada e subtratada. Relaciona-se à significativa morbidade, mortalidade e redução da qualidade de vida. A deficiência de estrogênio é o principal fator que contribui para a perda óssea após a menopausa. $O$ risco de fratura a partir dos 50 anos de idade é de cerca de $50 \%$ em mulheres. $\mathrm{O}$ objetivo do tratamento da osteoporose é a prevenção de fraturas. $\mathrm{O}$ tratamento não farmacológico envolve uma dieta saudável, prevenção de quedas e de programas de exercícios físicos. $O$ tratamento farmacológico inclui cálcio, vitamina $D$ e medicação ativa em tecido ósseo, tais como antirreabsortivos (SERMs, terapia de substituição hormonal, bifosfonatos, denosumabe), formadores de osso (PTH e análogos) e agentes mistos (ranelato de estrôncio). Os bisfosfonatos (alendronato, risedronato, ibandronato e zoledronato) são os mais utilizados agentes antirreabsortivos para o tratamento da osteoporose. A baixa aderência, a intolerância medicamentosa e os efeitos adversos podem limitar os benefícios do tratamento. Com base no conhecimento da sinalização entre as células ósseas, novos medicamentos foram desenvolvidos e estão sendo avaliados em ensaios clínicos. Arq Bras Endocrinol Metab. 2014;58(2):162-71

Descritores:

Osteoporose; tratamento; pós-menopausa; antirreabsortivos

\section{INTRODUCTION}

$\mathrm{P}$ ostmenopausal osteoporosis is a silent disease in most cases, with no symptoms until fractures occur. It is characterized by low bone mineral density (BMD) and changes in bone microarchitecture that reduce bone strength and increase fracture risk (1).

Estrogen deficiency is the major contributing factor to bone loss after menopause. Estrogens decrease during the climacteric period induce an increase in RANKligand (RANKL) and a decrease in osteoprotegerin
(OPG) secretion from osteoblasts. RANKL activates its RANK receptor on the surface of the pre-osteoclasts, which induces their differentiation and activation. This imbalance induces fast bone loss, and increases the risk of fractures.

This condition is frequently underdiagnosed and undertreated. The World Health Organization (WHO) has identified osteoporosis as a major public health concern, due to its high prevalence and the serious consequences of osteoporotic fractures (2). 
In the present, the lifetime fracture risk at 50 years of age is about $50 \%$ in women. Osteoporosis causes lasting disability, increased mortality, and poor quality of life. The cost of managing osteoporotic fractures imposes a huge burden on healthcare systems, and will increase over the next years because of the aging of the population (1).

The prevalence of osteoporosis shown in Brazilian studies is widely variable (from $22.2 \%$ to $33.8 \%$ ) because of differences in sample sizes, eligibility criteria, and methodologies (3). The prevalence of all types of bone fragility fracture is high, ranging from $11 \%$ to $23.8 \%$ associated with a high incidence of recurrent falls. Mortality rate ranges from $21.5 \%$ to $30 \%$, with a high rate of physical impairment, and deterioration of the quality of life (3).

In Brazil, annual osteoporosis treatment costs are 775 dollars per patient (postmenopausal women), according to Kowalski and cols (4). A probably underestimated cost of hip fracture in a Brazilian public hospital showed something around US\$ 3,940.00 for a mean of 11 days of hospitalization (5), and mortality rate after 6 months as high as $23.3 \%(6)$. In private hospitals, the mean hospitalization period for hip fractures was 9.21 days with a cost of US\$ $12,000.00$, mainly related to medical and surgical procedures (5).

The aim of osteoporosis treatment is to prevent fractures, and involves pharmacological and non-pharmacological approaches, and treatments which will be reviewed below.

\section{NON-PHARMACOLOGICAL TREATMENT}

Peak bone mass is achieved during the third decade of life, and it is mainly determined by genetic influence and, to a lesser extent, by the modifiable aspects in life style and health status. Factors such as nutrition, hormonal status, physical exercise, medical conditions, drug abuse, alcohol or tobacco can interfere with the peak of bone mass. Patients should be encouraged to stop smoking and reduce excessive alcohol and caffeine intake (7).

Fall prevention strategies should be discussed with the patients with focus on their homes. Some medical conditions need to be addressed such as dizziness, postural hypotension, poor vision, and inadequate footwear (7).

Several studies demonstrate that physical exercise programs including impact exercises, specific strength training, balance and coordination training may main- tain or increase spine and hip bone mineral density, as well as decrease the frequency of falls among osteoporotic and osteopenic patients (8).

\section{CALCIUM}

Prolonged low calcium intake leads to a negative calcium balance with compensatory secondary hyperparathyroidism, which increases bone resorption and the risk of fractures. According to the US Institute of Medicine (IOM), the recommended daily calcium intake for postmenopausal women is $1,200 \mathrm{mg}$, with an upper limit of 2,000 $\mathrm{mg}(9)$, preferentially obtained from the diet. This information can be assessed by a quick questionnaire and, if this goal is not met, the initial strategy is to incentivize consumption, especially of dairy products. If this is not possible, calcium supplements have to be considered. Pinheiro and cols. reported an average intake of $414 \mathrm{mg}$ a day in Brazilian postmenopausal women (10).

Many calcium salts are available but, carbonate and citrate are the most commonly used. Calcium carbonate has $40 \%$ elemental calcium, whereas citrate has $21 \%$. The dissolution of calcium citrate is less dependent on the presence of gastric acidity than carbonate. This condition is especially relevant for the elderly, the users of proton pump inhibitors and after bariatric surgery. It is not recommended that patients receive more than 500 mg per dose, to improve absorption. In some patients, nausea, dyspepsia, and constipation can follow calcium supplementation, reducing treatment compliance (11).

Recently, controversy has arisen based on reports of increased cardiovascular risk associated with calcium supplementation. Publications with the opposing view have also been recently published, including a metaanalysis and a randomized controlled trial with long term follow-up $(12,13)$. This leads to the question of whether calcium supplementation is beneficial for the bone system, but deleterious for the cardiovascular system. According to the ASBMR Professional Practice Committee in 2011, the weight of evidence is insufficient to conclude that calcium supplements cause adverse cardiovascular events; however, the debate still continues (14).

\section{VITAMIN D}

The contribution of diet as a source of vitamin D is very limited and its concentrations are mainly dependent on the skin formation after UVB radiation. The enormous 
social changes that occurred in the last century justify the high prevalence of vitamin D deficiency observed in virtually all regions of our planet. The aging of the population, the rise in obesity, the more reclusive habits in large cities, and the indiscriminate use of sunscreen have caused a currently generalized inadequate vitamin $\mathrm{D}$ status. Lower concentrations of vitamin D are associated with elevated levels of PTH and, consequently, high resorption rate, and high risk of fractures. The recognition of these changes allowed a recent review on the Table of Vitamin D intake recommendations by the Institute of Medicine, in the U.S.

The IOM recommends a vitamin $\mathrm{D}$ daily dietary allowance of $600 \mathrm{IU}$ for 51-70 years old women, and 800 IU for those older than 70 years old, with an upper limit of 4,000 IU (9). However, the Endocrine Society guideline recommends 1,500-2,000 IU daily, with an upper limit of 10,000 IU (15).

Vitamin D status is best assessed by measuring levels of $25(\mathrm{OH}) \mathrm{D}$. The IOM Committee considers $20 \mathrm{ng} /$ $\mathrm{mL}$ to be the level necessary for good bone health in practically all individuals (9). However, the American Endocrine Society strongly suggests that, for an adequate vitamin $\mathrm{D}$ status, $25(\mathrm{OH}) \mathrm{D}$ should be higher than $30 \mathrm{ng} / \mathrm{mL}$ (15). Many authors consider $30 \mathrm{ng} /$ $\mathrm{mL}$ as the lower limit of the normal range, because this level is associated with lower PTH concentrations, with greatest calcium absorption, highest bone mineral density (BMD), reduced rates of bone loss, reduced rates of falls, and reduced fracture rates (16). In adults with very low $25(\mathrm{OH}) \mathrm{D}$ levels (under $20 \mathrm{ng} / \mathrm{mL}$ ), a 7,000 IU daily or 50,000 units weekly, for 6 to 8 weeks or longer, may be necessary (15). In our experience, doses higher than 1,000 IU/day of vitamin $\mathrm{D}_{3}$ are necessary to maintain 25 -hydroxyvitamin D [25(OH)D] within normal range ( $>30 \mathrm{ng} / \mathrm{mL}$ ) in osteoporotic patients.

Vitamin D deficiency and insufficiency is very common in Brazil, especially among the elderly individuals, even in sunny regions. The main determinants are age, sex, latitude, ethnicity, and sunlight exposure $(17,18)$.

\section{HORMONE REPLACEMENT THERAPY (HRT)}

There is evidence that bone loss starts 2-3 years prior to the last menses, and it is accelerated with menopause due to estrogen deprivation. This process continues for up to 5-10 years. Estrogen deficiency is associated with an increase in the lifespan of osteoclasts and a concomitant decrease in osteoblast lifespan. It is also associated with increases in bone marrow levels of a number of pro-resorptive cytokines, including TNF- $\alpha$, IL- $1 \alpha$, and others (19). These cytokines expand the pool of osteoclast precursor cells, and increase expression of the key molecule regulating osteoclast development, activity, and lifespan: receptor activator of nuclear factor B ligand (RANKL), by osteoblasts and other cells in the bone microenvironment (19).

There is considerable evidence that even the low residual levels of estrogen present in postmenopausal women are important in reducing bone resorption, and that women with breast cancer treated with aromatase inhibitors are at increased risk of bone loss (19).

This suppression of osteoclast activity by estrogen replacement therapy has been used effectively for decades, and was the mainstay of prevention and treatment of postmenopausal osteoporosis. Nowadays, the primary indication is the treatment of moderate and severe menopausal symptoms (i.e., vasomotor symptoms, vaginal atrophy) (1).

Wells and cols. published a meta-analysis that used 57 randomized, placebo-controlled trials evaluating the effect of HRT in postmenopausal women. They demonstrated that estrogen was significantly more effective than placebo in preserving and increasing BMD, and the discontinuation of estrogen resulted in bone loss at a rate similar to that seen in early menopause (20).

In the same study, Wells and cols. observed that HRT showed a trend towards reduced incidence of vertebral fractures [relative risk (RR) $0.66,95 \%$ confidence interval (CI) $0.41-1.07 ; 5$ trials] and non-vertebral fractures (RR 0.87, 95\% CI 0.71-1.08; 6 trials) (20).

HRT is associated with an increased risk of adverse health outcomes in the long-term therapy, such as stroke and venous thromboembolic events. Women receiving estrogen and progestogen showed a small but significant increase in breast cancer in the Women's Health Initiative study. However, the use of isolated estrogen therapy in hysterectomized women reduced $23 \%$ the incidence of invasive breast cancer compared with placebo $(\mathrm{p}=0.06$, not significant) (2l).

\section{SELECTIVE ESTROGEN RECEPTOR MODULATORS (SERMS)}

SERMs bind to the estrogen receptor (ER) with high affinity, and mediate transcriptional events as an agonist (bone and cardiovascular system) or antagonist (breast and in some cases endometrium), depending on the 
target tissue. Raloxifene is approved for the prevention and treatment of postmenopausal osteoporosis (60 $\mathrm{mg} /$ day). The effects of raloxifene on markers of bone turnover have generally been more modest (e.g., 30$40 \%$ reduction) than with bisphosphonate therapy (5070\%) (22). The same response was observed in BMD (23). The MORE (Multiple Outcomes of Raloxifene Evaluation) study demonstrated a $30 \%$ reduction of vertebral fracture risk ( $\mathrm{RR}, 0.7 ; 95 \% \mathrm{CI}, 0.5-0.8)$, but not in non-vertebral fractures during a follow-up of 3 years (24). In the CORE study, an extension of the MORE study, it has been shown that raloxifene therapy had no effect on non-vertebral fracture risk after 8 years (25). Raloxifene also reduced the risk of ER-positiveinvasive breast cancer ( $\mathrm{RR}, 0.24 ; 95 \% \mathrm{CI}, 0.15-0.40)$ and endometrial cancer (RR, $0.62 ; 95 \% \mathrm{CI}, 0.35-1.08$ ) $(25,26)$. The RUTH (Raloxifene Use for The Heart) study, involving postmenopausal women with high risk of cardiovascular disease for 5 years, showed an increased risk of fatal stroke (HR, 1.49; 95\% CI, 1.002.24) and venous thromboembolism (HR, 1.44; 95\% CI, 1.06-1.95) (27).

In general, it is well tolerated, with transient occurrence of hot flushes and leg cramps in less than $10 \%$ of patients. Consequently, it is not recommended to symptomatic postmenopausal women (24).

Other new SERMs have been developed in recent years, but some were discontinued because of unacceptable efficacy, safety, and/or tolerability profiles.

The PEARL (Postmenopausal Evaluation and Risk Reduction with Lasofoxifene) Study evaluated the dose of $0.5 \mathrm{mg} / \mathrm{d}$ in 8,556 women, and showed a reduction of the vertebral fracture risk by $42 \%$ ( $\mathrm{HR}, 0.58 ; 95 \%$ CI, 0.47-0.70) at 3 years, and non-vertebral fractures by $24 \%$ (HR $0.76 ; 95 \% \mathrm{CI}, 0.64-0.91)$ at 5 years; risk of ER positive breast cancer (HR $0.19 ; 95 \%$ CI, 0.07 0.56 ), coronary heart disease (HR 0.68 ; 95\% CI, 0.50 0.93), and stroke (HR, 0.64; 95\% CI, 0.41-0.99), but increased the risk of venous thromboembolic events, vasomotor symptoms, and leg cramps. There was also an increased risk of uterine polyps and endometrial hypertrophy, but no increased risk of endometrial cancer or hyperplasia (28).

A 5-year study of bazedoxifene (20 or $40 \mathrm{mg}$ ) showed a reduction of 35 and $40 \%$ of the risk of vertebral fractures, respectively. There was an increase in $\mathrm{BMD}$, reduced bone turnover marker levels, and favorable effects on lipid parameters. In a post-hoc analysis of a subgroup at high risk of fracture, the $20-\mathrm{mg}$ dose sig- nificantly reduced the risk of non-vertebral fracture by $37 \%$ compared with the placebo. There was no stimulatory effect on the endometrium, but it was associated with increased vasomotor symptoms, leg cramps, and venous thromboembolism (29).

Both bazedoxifene and lasofoxifene have been approved for use in treatment of postmenopausal osteoporosis in the European Union, but they are not available in Brazil.

\section{BISPHOSPHONATES}

Bisphosphonates are the most used anti-resorptive agents in the world for the treatment of osteoporosis and are in use for three decades. They are synthetic analogues of pyrophosphate, with high affinity for hydroxyapatite. They strongly bind to the mineralized tissue, especially in the active remodeling sites. They are removed from bone by osteoclasts during resorption and are not metabolized for excretion. Therefore, they can be rebound by the mineralized tissue again. Because of their characteristics, they can remain as long as 10 years in the skeleton. Variations in the structure of the amino side chains of these drugs affect their pharmacological activity in terms of bone affinity and potency. The most potent molecules have a nitrogen-containing chain, such as alendronate, risedronate, ibandronate, and zoledronate. Skeleton-binding affinity increases in this rank order: risedronate, ibandronate, alendronate, and zoledronate $(30)$.

The mechanism of action is the inhibition of farnesyl diphosphate synthase, an enzyme of the mevalonate pathway, and prevention of the prenylation of GTPbinding proteins, essential in the cytoskeletal osteoclast function and metabolism. Basically, bisphosphonates decrease bone turnover leading osteoclasts to apoptosis. The rank order of potency for inhibiting farnesyl diphosphate synthase is zoledronate $<$ risedronate $<i b a n d$ ronate $<$ alendronate $(30,31)$. The increase of bone mass observed in many trials is related to the secondary mineralization of the preformed osteons, and not because of increased bone formation (32).

Alendronate can be given orally once a week (70 $\mathrm{mg})$, ibandronate once a month $(150 \mathrm{mg})$, and risedronate once a week or once a month $(35 \mathrm{mg}$ and 150 $\mathrm{mg}$, respectively). Oral bisphosphonates are poorly absorbed (less than 1\%), and the dose has to be administered with plain water only, after an overnight fast, and followed by 30-60 minutes without eating or drink- 
ing. The patients need to stand upright for one hour to prevent gastroesophageal reflux and damage to the mucosa $(30,31)$.

Ibandronate can also be given intravenously (IV) every 3 months ( $3 \mathrm{mg}$ ), and zoledronate once a year (5 mg IV). The main side effect of this administration is an auto-limited flu-like syndrome (acute phase reaction) due to release of cytokines (TNF- $\alpha$, IFN- $\gamma$, and IL-6), causing mild fever and muscle pain that can be controlled with anti-pyretic drugs. This reaction usually subsides in 1 or 2 days, and gets milder with the subsequent infusions $(30,31)$.

Fifty per cent of the absorbed dose binds to the bones, and the rest is excreted in the urine. Renal toxicity may occur with rapid IV administration. Use is not recommended for patients with creatinine clearance lower than 30-35 mL/min. These compounds should be used with caution in pre-menopausal women of childbearing potential, because their effects in human fetus are still unknown $(30,31)$.

Alendronate was the first bisphosphonate approved by the FDA for the prevention and treatment of osteoporosis. The once-weekly administration $(70 \mathrm{mg}) \mathrm{im}$ proved the use and tolerability with the same or better efficacy than the daily therapy $(10 \mathrm{mg})(33)$. In the FIT (Fracture Intervention Trial) study, there was a $47 \%$ reduction in new morphometric vertebral fractures $(R R$, $0.53 ; 95 \%$ CI $0.41-0.68$ ), and $51 \%$ in hip fractures (RR, $0.49 ; 95 \% \mathrm{CI}, 0.23-0.99)$ in individuals with one prior vertebral fracture at least (34). In those without fractures, alendronate reduced the risk of radiographic vertebral fractures in $44 \%$ (RR, 0.56 ; 95\% CI, 0.39-0.80) in 4 years (35). In the FOSIT (Fosamax International Trial) study, alendronate reduced the risk of non-vertebral fractures in $47 \%$ (36). In the FLEX (Fracture Intervention Trial Long-term Extension) study, switching to placebo for 5 years resulted in declines in BMD in total hip and spine, but mean levels remained at or above pretreatment levels 10 years earlier. After 5 years, the cumulative risk of non-vertebral fractures (RR, 1.00; 95\% CI, 0.76-1.32) was not significant. Among those who continued, there was a significantly lower risk of clinically recognized vertebral fractures (RR, 0.45; 95\% CI, 0.24-0.85), but no significant reduction in morphometric vertebral fractures (37).

Risedronate was evaluated in the US and multinational VERT (Vertebral Efficacy With Risedronate Therapy) studies, showing a reduction of new vertebral (41\% and $49 \%$, respectively) and non-vertebral fractures
(39\% and $33 \%$, respectively) during 3 years, at least in women with prior vertebral fracture (38). In the Hip Intervention Program Study Group, risedronate showed a reduction of $40 \%$ in women with osteoporosis (RR, 0.6 ; 95\% CI, 0.4-0.9) (39). Risedronate is given in a once a week (35 mg) or monthly (150 mg) dose.

An oral daily dose $(2.5 \mathrm{mg})$ and an intermittent dose (20 mg every other day for 12 doses every 3 months) of ibandronate were evaluated in the BONE (oral iBandronate Osteoporosis vertebral fracture Trial in North America and Europe) study. After 3 years, daily and intermittent oral ibandronate significantly reduced the risk of new morphometric vertebral fractures by $62 \%$ and $50 \%$, respectively, versus placebo. The overall population was at low risk of osteoporotic fractures. Consequently, the incidence of non-vertebral fractures was similar between the ibandronate and placebo groups. However, findings from a post-hoc analysis showed that the daily regimen reduced the risk of non-vertebral fractures $(69 \%)$ in a higher-risk subgroup (femoral neck BMD T-score < -3.0) (40). The MOBILE (Monthly Oral IBandronate In LadiEs) study, evaluated the monthly dose $(50 / 50$, 100 , and $150 \mathrm{mg}$ ) compared with the daily regimen during 2 years. All monthly regimens were proven to be non-inferior, and the $150 \mathrm{mg}$ regimen superior, to the daily regimen. All monthly regimens produced similar hip BMD gains, which were greater than those of the daily regimen (41). The DIVA (Dosing IntraVenous Administration) study compared two regimens of intermittent intravenous injections of ibandronate $(2 \mathrm{mg}$ every 2 months, and $3 \mathrm{mg}$ every 3 months) with a regimen of $2.5 \mathrm{mg}$ of oral ibandronate daily, which are at least as effective as the daily regimen of $2.5 \mathrm{mg}$ by oral route. The primary endpoint was different from baseline in lumbar spine BMD at 1 year (42).

The HORIZON (Health Outcomes and Reduced Incidence with Zoledronic Acid Once Yearly) study evaluated the efficacy of $5 \mathrm{mg}$ zoledronate during 3 years. There was a reduction of the risk of morphometric vertebral fracture by $70 \%(\mathrm{RR}, 0.30 ; 95 \% \mathrm{CI}, 0.24$ 0.38 ), and hip fracture by $41 \%(\mathrm{HR}, 0.59 ; 95 \% \mathrm{CI}$, $0.42-0.83)$. Non-vertebral fractures, clinical fractures, and clinical vertebral fractures were reduced by $25 \%$, $33 \%$, and $77 \%$, respectively (43). A reduction of $35 \%$ in new clinical fractures in patients with prior fractures was documented in another study, along with a reduction in mortality (28\%) (44). Recently, the extension FPT (HORIZON-Pivotal Fracture Trial) study showed the benefits of a 6-year treatment of zoledronate. 
In years 3 to 6 , femoral neck BMD remained constant in the zoledronate group, and dropped slightly in the discontinuing group (between-treatment difference = 1.04\%; 95\% CI, 0.4-1.7) but remained above pretreatment levels. Other BMD sites showed similar differences. New morphometric vertebral fractures were lower in the zoledronate group (odds ratio $=0.51$ ), whereas other fractures were not different (45).

The most common adverse events reported with the use of oral bisphosphonates are related with gastroesophageal intolerance, reported in up to $10 \%$ of trial participants $(46,47)$. An increased risk of atrial fibrillation was reported in the HORIZON trial (43), but other observational studies have failed in detecting an increased risk with any of the bisphosphonates (47).

Osteonecrosis of the jaw (ONJ) has been reported primarily in patients with cancer who have received large and cumulative doses of intravenous bisphosphonates. This condition is defined as exposure of necrotic bone in the oral cavity, not healing for 6-8 weeks, in the absence of radiotherapy and jaw metastases. In patients with osteoporosis treated with bisphosphonates, $\mathrm{ONJ}$ is rare, accounting for $0.8-5.0 \%$ of the reported cases, and no cases have been identified in clinical trials with alendronate, ibandronate, or risedronate. In the HORIZON-FPT, two cases of $\mathrm{ONJ}$ were reported among 7,765 patients, one in the placebo, and one in the zoledronate group (43). The incidence of $\mathrm{ONJ}$ is estimated at $0.9 / 100,000$ patient-years of treatment among patients who receive oral bisphosphonate therapy, and the causal association is unproven $(30,46,47)$. According to the American Dental Association General Treatment Recommendations 2011, practitioners generally should not modify routine dental treatment solely because of the use of anti-resorptive agents. An oral health program consisting of sound hygiene practices and regular dental care may be the optimal approach for lowering ONJ risk. No validated diagnostic technique exists to determine which patients are at increased risk of developing ONJ. Discontinuing bisphosphonate therapy may not lower the risk, but may have a negative effect on low-bone-masstreatment outcomes (48).

Cases of atypical low-trauma subthrocanteric and femoral shaft fractures have been reported in patients receiving long-term bisphosphonates. Prior to the fracture, patients reported prodromal symptoms of pain (typically groin or thigh). Radiographic findings are the thickening of the cortex in the lateral aspect of the proximal femur, which is the site of high tensional stresses.
A complete atypical fracture is displayed in addition to a straight transverse fracture line and median cortical spiking (7). Attention has been drawn to an association between this kind of fractures and the use of bisphosphonates, possibly related to long-term suppression of bone turnover $(30,47)$. However this hypothesis comes from retrospective case series with small numbers of patients involved. There is no randomized controlled trial evidence of an increase in the risk of atypical fractures. There is also a possible association of reduced bone turnover induced by bisphosphonates and the other risk factors, such as younger age at beginning or concomitant therapy with corticosteroids, proton pump inhibitors, or other anti-resorptive agents $(30,47)$.

The ideal duration of treatment with bisphosphonates is uncertain at this time. There is considerable evidence showing that anti-resorptive agents are effective in reducing fracture risk, and that they are well tolerated for over 3 to 5 years. It is a reasonable question when considering bisphosphonate therapy, however, because these drugs accumulate in the skeleton, leading to a reservoir that continues to be released for months or years after treatment is discontinued. Stopping alendronate after 10 years of treatment at a dose of $10 \mathrm{mg}$ daily (which should be the same of $70 \mathrm{mg}$ weekly), the amount of alendronate released from bone over the next several months or years would be equivalent to taking one fourth of the usual dose $(2.5 \mathrm{mg}$ daily or $70 \mathrm{mg}$ once a month). There is a concern that long-term treatment has the potential to oversuppress bone remodeling and inhibit repair of microdamage, cause excessive mineralization, and cause an increase in microcracks. The data from the FLEX trial (37) suggest that a subset of patients may safely take a break from alendronate after 5 years of therapy without experiencing a rapid decline in BMD. The data suggest that, although there is some residual benefit in terms of fracture reduction for some time after a 3- to 5-year course of bisphosphonate therapy, continuing treatment for 10 years is better for some patients (high risk of fracture). Decisions regarding discontinuation must be individualized and based upon the assessment of ongoing fracture risk (30).

\section{CALCITONIN}

The PROOF (Prevent Recurrence Of Osteoporotic Fractures) study showed that a dose of 200 IU of salmon calcitonin nasal spray significantly reduced the risk 
of new vertebral fractures by $33 \%$ (RR, $0.67,95 \% \mathrm{CI}$, $0.47-0.97$ ) and $36 \%$ in women with prevalent fractures $(\mathrm{RR}=0.64,95 \% \mathrm{CI}, 0.43-0.96)$. Occasional rhinitis can occur. Headache, flushing, nausea and diarrhea have been reported more commonly with subcutaneous dose than with intranasal calcitonin. There is no data on hip or non-vertebral fracture risk reduction (49). Nowadays, calcitonin is relegated to second or third place as the agent of choice for the treatment of osteoporosis.

\section{DENOSUMAB}

Denosumab is a human monoclonal antibody that inhibits RANKL and, consequently, osteoclastogenesis. It is administered as a $60-\mathrm{mg}$ subcutaneous injection every 6 months. Its clearance occurs by means of the reticuloendothelial system and not by renal excretion. Therefore, denosumab can be given to patients with renal impairment. The FREEDOM (Fracture Reduction Evaluation of Denosumab in Osteoporosis Every 6 Months) trial evaluated the efficacy of denosumab during 3 years; the treated group had significant gains in lumbar spine (9.4\%) and total hip BMD (4.8\%). Denosumab reduced the risk of new radiographic vertebral fracture in $68 \%(\mathrm{RR}, 0.32 ; 95 \% \mathrm{CI}, 0.26-0.41)$, hip fracture in $40 \%$ ( $\mathrm{HR}, 0.60 ; 95 \% \mathrm{CI}, 0.37-0.97)$ and non-vertebral fracture in $20 \%$ (HR $0.80 ; 95 \% \mathrm{CI}$, 0.67-0.95). Cellulitis was more frequent in patients taking denosumab compared with the placebo $(0.3 \%$ vs. $<0.1 \%)$, although the absolute risk was very low (50). In the long-term group, BMD further increased in cumulative 6-year gains of $15.2 \%$ (lumbar spine) and $7.5 \%$ (total hip). In the long-term group, fracture incidence remained low and rare cases of ONJ have been reported (51). Patients discontinuing denosumab experienced a fast decrease in BMD during the first 12 months, with the subsequent rate of BMD losses being similar to the placebo, demonstrating that denosumab does not confer a residual effect following cessation of therapy (52). Long-term treatment with denosumab was associated with a sustained increase on BMD, as well as low bone markers, and maintained the vertebral and non-vertebral anti-fracture efficacy over 6 years. Six participants had events of ONJ confirmed by adjudication. One participant had a fracture adjudicated as consistent with atypical femoral fracture (51).

\section{TERIPARATIDE}

Intermittent administration of low-dose PTH enhances osteoblast activity and bone formation. Two PTH peptides have been approved for the treatment of osteoporosis: teriparatide (PTH 1-34) and PTH 1-84, but only teriparatide is available in Brazil. It is administered as a $20-\mathrm{mcg}$ subcutaneous daily injection. There was a $65 \%$ and $54 \%$ reduction in fracture risk in vertebral and non-vertebral fractures. Due to a small number of hip fractures, no significant fracture risk reduction was demonstrated (53). The concomitant use of bisphosphonates may attenuate bone mass improvement seen with PTH alone, but the administration of an anti-resorptive agent has to be considered after the treatment in order to maintain the bone gain achieved (54). Maximum treatment duration of 2 years is recommended because preclinical studies showed the development of osteosarcoma in rats (53). Asymptomatic hypercalcemia, occasional nausea, dizziness, leg cramps, and headache were associated with teriparatide use. Teriparatide is contraindicated in clinical situations with high risk of osteosarcoma, such as children and adolescents, Paget's disease, bone metastasis, skeletal irradiation, or unexplained elevations of alkaline phosphatase. The use of teriparatide is limited to severe osteoporosis because of the high cost of the treatment.

\section{STRONTIUM RANELATE}

Strontium ranelate contains two atoms of strontium, which is a divalent cation, like calcium. It has a dual action, increasing bone formation and decreasing resorption, but its exact mechanism of action is still unclear. The SOTI (Spinal Osteoporotic Therapeutic Intervention) trial showed a risk reduction of $49 \%$ in the first year of treatment with $2 \mathrm{~g}$ daily, and of $41 \%$ during the three-year study (RR, 0.59; 95\% CI, 0.48-0.73) (55). The TROPOS (TReatment Of Peripherial OSteoporosis) trial showed a reduction of $19 \%$ on non-vertebral fracture, and among women at high risk of hip fracture, the reduction for hip fracture was $36 \%$ (56). The most common side effects were nausea, diarrhea, and mild and transient elevation in creatine kinase. It is contraindicated in patients at high risk of thromboembolic events. A few cases of hypersensitivity were described, with eosinophilia and systemic symptoms. Long-term treatment with strontium ranelate was safe and associated with a sustained increase on BMD and in the anti-fracture efficacy over 
10 years (57). As strontium has a higher atomic number than calcium, it attenuates more X-rays than calcium does. This attenuation can result in an overestimation of BMD that requires an adjustment for bone strontium content (58).

\section{NEW OSTEOPOROSIS TARGETS AND NEW MECHANISMS OF ACTION}

\section{Cathepsin K inhibitors - Odanacatib}

Cathepsin $\mathrm{K}$ is a lisossomal enzyme produced by the osteoclast to break down the bone matrix during resorption process, and odanacatib (ODN) is a specific inhibitor of this enzyme. The phase II study showed that women receiving odanacatib for 5 years gained BMD in spine and hip, with larger reductions in bone resorption than in bone formation markers. Discontinuation of ODN resulted in reversal on these effects, with fast bone loss. Treatment with ODN for up to 5 years was generally well-tolerated (59).

\section{Antiesclerostin antibodies}

Sclerostin is a protein produced almost exclusively by osteocytes and its function is to prevent the Wnt signaling in osteoblasts. The activation of Wnt pathway in the cell membrane of osteoblasts strongly induces bone formation. New monoclonal antibodies against sclerostin have been developed and are new promising therapeutic goal for osteoporosis.

\section{CONCLUSION}

In summary, osteoporosis is a very common clinical situation, with an expected trend to and increasing incidence in the next decades due to the worldwide aging of the population. Bone loss and fractures follow the decrease in estrogen levels in the postmenopausal period, which increases osteoclast activity and, subsequently, bone resorption. The adequacy of calcium intake and vitamin D status are priority measures before starting osteoporosis treatment with specific drugs, as well as encouraging physical activity and prevention of falls. Several drugs are already available with proven efficacy against fractures and excellent safety profiles. The challenge today is to improve the detection of osteoporosis and convince healthcare professionals to refer at-risk patients for treatment.
Disclosure: S. S. Maeda is a speaker for Eli Lilly do Brasil and Sanofi, and M. Lazaretti-Castro has received research grants from Amgen, Eli Lilly do Brasil, and MSD, and speaker and consultant fees from Eli Lilly do Brasil, Sanofi, and Mantecorp-Farmasa.

Note: After this article was accepted, a new statement of European Medicines Agency (EMA) was published with restrictions on the use of strontium ranelate caused by some data showing an increased risk of cardiovascular disease in patients receiving this treatment. The recommendations are that strontium ranelate should only be used to treat severe osteoporosis in postmenopausal women and men at high risk of fracture, for whom treatment with other medicinal products approved for the treatment of osteoporosis is not possible due to, for example, contraindications or intolerance. Strontium ranelate must not be used in patients with established, current or past history of ischaemic heart disease, peripheral arterial disease and/or cerebrovascular disease, those with uncontrolled hypertension, venous thromboembolic event, or temporary or permanent immobilization*.

* European Medicines Agency (EMA). Available: http://www. ema.europa.eu/ema/index.jsp?curl=pages/medicines/human/ referrals/Protelos_and_Osseor/human_referral_prac_000025. jsp\&mid=WC0b01ac05805c516f.

\section{REFERENCES}

1. North American Menopause Society. Management of osteoporosis in postmenopausal women: 2006 position statement of The North American Menopause Society. Menopause. 2006;13:340-67.

2. Kanis JA, WHO Study Group. Assessment of fracture risk and its applications to screening for postmenopausal osteoporosis: synopsis of a WHO report. Osteoporosis Int. 1994;4:368-81.

3. Pinheiro MM, Eis SR. Epidemiology of osteoporotic fractures in Brazil: what we have and what we need. Arq Bras Endocrinol Metab. 2010;54(2):164-70.

4. Kowalski SC, Szenjfeld VL, Ferraz MB. Resource utilization in postmenopausal osteoporosis without incident fractures. J Reumathol. 2004;31(5):938-42.

5. Araujo DV, Oliveira JH, Bracco OL. Cost of osteoporotic hip fractures in the Brazilian private health care system. Arq Bras Endocrinol Metab. 2005;49(6):897-901.

6. Fortes EM, Raffaelli MP, Bracco OL, Takata ET, Reis FB, Santili C, et al. [High morbid-mortability and reduced level of osteoporosis diagnosis among elderly people who had hip fractures in São Paulo City]. Arq Bras Endocrinol Metabol. 2008;52(7):1106-14.

7. Daroszewska A. Prevention and treatment of osteoporosis in women: an update. Obstet Gynaecol Reprod Med. 2012;22(6):162-9.

8. Lirani-Galvão APR, Lazaretti-Castro M. Physical approach for prevention and treatment of osteoporosis. Arq Bras Endocrinol Metab. 2010;54(2):171-8.

9. IOM (Institute of Medicine). Dietary reference intakes for calcium and vitamin D. Washington, DC: The National Academies; 2011.

10. Pinheiro MM, Schuch NJ, Genaro PS, Ciconelli RM, Ferraz MB, Martini LA. Nutrient intakes related to osteoporotic fractures in men and women -- the Brazilian Osteoporosis Study (BRAZOS). Nutr J. 2009;8:6.

11. Pinto Neto AM, Soares A, Urbanetz AA, Souza ACA, Ferrari AEM, Amaral B, et al. Consenso brasileiro de osteoporose 2002. Rev. Bras. Reumatol 2002;42(6):343-54. 
12. Bolland MJ, Avenell A, Baron JA, Grey A, MacLennan GS, Gamble GD, et al. Effect of calcium supplements on risk of myocardial infarction and cardiovascular events: meta-analysis. BMJ. 2010;341:c3691.

13. Wang L, Manson JE, Sesso HD. Calcium intake and risk of cardiovascular disease: a review of prospective studies and randomized clinical trials. Am J Cardiovasc Drugs. 2012;12(2):10516.

14. Bockman RS, Zapalowski C, Kiel DP, Adler RA. Commentary on calcium supplements and cardiovascular events. J Clin Densitom. 2012;15(2):130-4.

15. Holick MF, Binkley NC, Bischoff-Ferrari HA, Gordon CM, Hanley DA, Heaney RP, et al. Evaluation, treatment, and prevention of vitamin D deficiency: an Endocrine Society clinical practice guideline. J Clin Endocrinol Metab. 2011;96(7):1911-30.

16. Dawson-Hughes B, Heaney RP, Holick MF, Lips P, Meunier PJ, Vieth R. Estimates of optimal vitamin D status. Osteoporos Int. 2005;16(7):713-6.

17. Arantes HP, Kulak CA, Fernandes $C E$, Zerbini $C$, Bandeira $F$, Barbosa IC, et al. Correlation between 25-hydroxyvitamin D levels and latitude in Brazilian postmenopausal women: from the Arzoxifene Generations Trial. Osteoporos Int. 2013;24(10):2707-12.

18. Maeda SS, Saraiva GL, Kunii IS, Hayashi LF, Cendoroglo MS, Ramos $L R$, et al. Factors affecting vitamin $D$ status in different populations in the city of Sao Paulo, Brazil: the Sao PAulo vitamin D Evaluation Study (SPADES). BMC Endocr Disord. 2013;13(1):14.

19. Khosla S. Update on estrogens and the skeleton. J Clin Endocrinol Metab. 2010;95(8):3569-77.

20. Wells G, Tugwell P, Shea B, Guyatt G, Peterson J, Zytaruk N, et al. Meta-analyses of therapies for postmenopausal osteoporosis. $V$. Meta-analysis of the efficacy of hormone replacement therapy in treating and preventing osteoporosis in postmenopausal women. Endocr Rev. 2002;23:529-39.

21. Anderson GL, Limacher $M$, Assaf AR, Bassford $T$, Beresford $S A$, Black $\mathrm{H}$, et al.; Women's Health Initiative Steering Committee. Effects of conjugated equine estrogen in postmenopausal women with hysterectomy: the Women's Health Initiative randomized controlled trial. JAMA. 2004;291(14):1701-12.

22. Johnell O, Scheele WH, Lu Y, Reginster JY, Need AG, Seeman E. Additive effects of raloxifene and alendronate on bone density and biochemical markers of bone remodeling in postmenopausal women with osteoporosis. J Clin Endocrinol Metab. 2002;87(3):985-92.

23. Sambrook PN, Geusens P, Ribot C, Solimano JA, FerrerBarriendos J, Gaines $\mathrm{K}$, et al. Alendronate produces greater effects than raloxifene on bone density and bone turnover in postmenopausal women with low bone density: results of EFFECT (Efficacy of FOSAMAX versus EVISTA Comparison Trial) International. J Intern Med. 2004;255(4):503-11.

24. Ettinger B, Black DM, Mitlak BH, Knickerbocker RK, Nickelsen $\mathrm{T}$, Genant HK, et al. Reduction of vertebral fracture risk in postmenopausal women with osteoporosis treated with raloxifene: results from a 3-year randomized clinical trial. Multiple Outcomes of Raloxifene Evaluation (MORE) Investigators. JAMA. 1999;282(7):637-45.

25. Siris ES, Harris ST, Eastell R, Zanchetta JR, Goemaere S, DiezPerez A, et al.; Continuing Outcomes Relevant to Evista (CORE) Investigators. Skeletal effects of raloxifene after 8 years: results from the continuing outcomes relevant to Evista (CORE) study. $J$ Bone Miner Res. 2005;20(9):1514-24.

26. Vogel VG, Costantino JP, Wickerham DL, Cronin WM, Cecchini RS, Atkins $\mathrm{JN}$, et al. Effects of tamoxifen vs raloxifene on the risk of developing invasive breast cancer and other disease outcomes: the NSABP Study of Tamoxifen and Raloxifene (STAR) P-2 trial. JAMA. 2006;295(23):2727-41.
27. Barrett-Connor E, Mosca L, Collins P, Geiger MJ, Grady D, Kornitzer M, et al.; Raloxifene Use for The Heart (RUTH) Trial Investigators. Effects of raloxifene on cardiovascular events and breast cancer in postmenopausal women. $\mathrm{N}$ Engl $\mathrm{J}$ Med. 2006;355(2):125-37.

28. Cummings SR, Ensrud K, Delmas PD, LaCroix AZ, Vukicevic $S$, Reid DM, et al.; PEARL Study Investigators. Lasofoxifene in postmenopausal women with osteoporosis. N Engl J Med. 2010;362(8):686-96.

29. Silverman $S L$, Chines AA, Kendler DL, Kung AW, Teglbjærg CS, Felsenberg D, et al.; Bazedoxifene Study Group. Sustained efficacy and safety of bazedoxifene in preventing fractures in postmenopausal women with osteoporosis: results of a 5-year, randomized, placebo-controlled study. Osteoporos Int. 2012;23(1):351-63.

30. Watts NB, Diab DL. Long-term use of bisphosphonates in osteoporosis. J Clin Endocrinol Metab. 2010;95(4):1555-65.

31. Fleisch H. Bisphosphonates: mechanisms of action. Endocr Rev. 1998;19(1):80-100.

32. Boivin GY, Chavassieux PM, Santora AC, Yates J, Meunier PJ. Alendronate increases bone strength by increasing the mean degree of mineralization of bone tissue in osteoporotic women. Bone. 2000;27:687-94.

33. Schnitzer T, Bone HG, Crepaldi G, Adami S, McClung M, Kiel D, et al. Therapeutic equivalence of alendronate $70 \mathrm{mg}$ once-weekly and alendronate $10 \mathrm{mg}$ daily in the treatment of osteoporosis. Alendronate Once-Weekly Study Group. Aging (Milano). 2000;12(1):1-12.

34. Black DM, Cummings SR, Karpf DB, Cauley JA, Thompson DE, Nevitt MC, et al. Randomised trial of effect of alendronate on risk of fracture in women with existing vertebral fractures. Fracture Intervention Trial Research Group. Lancet. 1996;348(9041):153541.

35. Cummings SR, Black DM, Thompson DE, Applegate WB, BarrettConnor E, Musliner TA, et al. Effect of alendronate on risk of fracture in women with low bone density but without vertebral fractures: results from the Fracture Intervention Trial. JAMA. 1998;280(24):2077-82.

36. Pols HA, Felsenberg D, Hanley DA, Stepán J, Muñoz-Torres M, Wilkin TJ, et al. Multinational, placebo-controlled, randomized trial of the effects of alendronate on bone density and fracture risk in postmenopausal women with low bone mass: results of the FOSIT study. Fosamax International Trial Study Group. Osteoporos Int. 1999;9(5):461-8.

37. Black DM, Schwartz AV, Ensrud KE, Cauley JA, Levis S, Quandt SA, et al.; Cummings SR; FLEX Research Group. Effects of continuing or stopping alendronate after 5 years of treatment: the Fracture Intervention Trial Long-term Extension (FLEX): a randomized trial. JAMA. 2006;296(24):2927-38.

38. Reginster J, Minne HW, Sorensen OH, Hooper M, Roux C, Brandi $\mathrm{ML}$, et al. Randomized trial of the effects of risedronate on vertebral fractures in women with established postmenopausal osteoporosis. Vertebral Efficacy with Risedronate Therapy (VERT) Study Group. Osteoporos Int. 2000;11(1):83-91.

39. McClung MR, Geusens P, Miller PD, Zippel H, Bensen WG, Roux C, et al.; Hip Intervention Program Study Group. Effect of risedronate on the risk of hip fracture in elderly women. Hip Intervention Program Study Group. N Engl J Med. 2001;344(5):333-40.

40. Chesnut III $\mathrm{CH}$, Skag A, Christiansen $\mathrm{C}$, Recker R, Stakkestad $\mathrm{JA}$, Hoiseth A, et al.; Oral Ibandronate Osteoporosis Vertebral Fracture Trial in North America and Europe (BONE). Effects of oral ibandronate administered daily or intermittently on fracture risk in postmenopausal osteoporosis. J Bone Miner Res. 2004;19(8):1241-9. 
41. Miller PD, McClung MR, Macovei L, Stakkestad JA, Luckey $M$, Bonvoisin B, et al. Monthly oral ibandronate therapy in postmenopausal osteoporosis: 1-year results from the MOBILE study. J Bone Miner Res. 2005;20(8):1315-22.

42. Delmas PD, Adami S, Strugala C, Stakkestad JA, Reginster $J Y$, Felsenberg $D$, et al. Intravenous ibandronate injections in postmenopausal women with osteoporosis: one-year results from the dosing intravenous administration study. Arthritis Rheum. 2006;54(6):1838-46.

43. Black DM, Delmas PD, Eastell R, Reid IR, Boonen S, Cauley JA, et al.; HORIZON Pivotal Fracture Trial. Once-yearly zoledronic acid for treatment of postmenopausal osteoporosis. N Engl J Med. 2007;356(18):1809-22.

44. Lyles KW, Colón-Emeric CS, Magaziner JS, Adachi JD, Pieper $\mathrm{CF}$, Mautalen $\mathrm{C}$, et al.; for the HORIZON Recurrent Fracture Trial. Zoledronic Acid in Reducing Clinical Fracture and Mortality after Hip Fracture. NEJM. 2007;357:nihpa40967.

45. Black DM, Reid IR, Boonen S, Bucci-Rechtweg C, Cauley JA, Cosman $F$, et al. The effect of 3 versus 6 years of zoledronic acid treatment of osteoporosis: a randomized extension to the HORIZON-Pivotal Fracture Trial (PFT). J Bone Miner Res. 2012;27(2):243-54.

46. Boonen S, Ferrari S, Miller PD, Eriksen EF, Sambrook PN, Compston J, et al. Postmenopausal osteoporosis treatment with antiresorptives: effects of discontinuation or long-term continuation on bone turnover and fracture risk--a perspective. $J$ Bone Miner Res. 2012;27(5):963-74.

47. Rizzoli R, Reginster JY, Boonen S, Bréart G, Diez-Perez $A$, Felsenberg $D$, et al. Adverse reactions and drug-drug interactions in the management of women with postmenopausal osteoporosis. Calcif Tissue Int. 2011;89(2):91-104.

48. Hellstein JW, Adler RA, Edwards B, Jacobsen PL, Kalmar JR, Koka S, et al.; American Dental Association Council on Scientific Affairs Expert Panel on Antiresorptive Agents. Managing the care of patients receiving antiresorptive therapy for prevention and treatment of osteoporosis: executive summary of recommendations from the American Dental Association Council on Scientific Affairs. J Am Dent Assoc. 2011;142(11):1243-51.

49. Chesnut CH 3rd, Silverman S, Andriano K, Genant H, Gimona A, Harris $S$, et al. A randomized trial of nasal spray salmon calcitonin in postmenopausal women with established osteoporosis: the prevent recurrence of osteoporotic fractures study. PROOF Study Group. Am J Med. 2000;109(4):267-76.
50. Cummings SR, San Martin J, McClung MR, Siris ES, Eastell R, Reid IR, et al.; FREEDOM Trial. Denosumab for prevention of fractures in postmenopausal women with osteoporosis. N Engl J Med. 2009;361(8):756-65.

51. Bone HG, Chapurlat R, Brandi ML, Brown JP, Czerwinski E, Krieg $M A$, et al. The effect of three or six years of denosumab exposure in women with postmenopausal osteoporosis: results from the FREEDOM extension. J Clin Endocrinol Metab. 2013;98(11):4483-92.

52. Bone HG, Bolognese MA, Yuen CK, Kendler DL, Miller PD, Yang $\mathrm{YC}$, et al. Effects of denosumab treatment and discontinuation on bone mineral density and bone turnover markers in postmenopausal women with low bone mass. J Clin Endocrinol Metab. 2011;96(4):972-80.

53. Neer RM, Arnaud CD, Zanchetta JR, Prince R, Gaich GA, Reginster $J Y$, et al. Effect of parathyroid hormone (1-34) on fractures and bone mineral density in postmenopausal women with osteoporosis. N Engl J Med. 2001;344(19):1434-41.

54. Black DM, Greenspan SL, Ensrud KE, Palermo L, McGowan JA, Lang TF, et al.; PaTH Study Investigators. The effects of parathyroid hormone and alendronate alone or in combination in postmenopausal osteoporosis. N Engl J Med. 2003;349(13):1207-15.

55. Meunier PJ, Roux C, Seeman E, Ortolani S, Badurski JE, Spector TD, et al. The effects of strontium ranelate on the risk of vertebral fracture in women with postmenopausal osteoporosis. N Engl J Med. 2004;350(5):459-68.

56. Reginster JY, Seeman E, De Vernejoul MC, Adami S, Compston $J$, Phenekos $C$, et al. Strontium ranelate reduces the risk of nonvertebral fractures in postmenopausal women with osteoporosis: Treatment of Peripheral Osteoporosis (TROPOS) study. J Clin Endocrinol Metab. 2005;90(5):2816-22.

57. Reginster JY, Kaufman JM, Goemaere S, Devogelaer JP, Benhamou CL, Felsenberg D, et al. Maintenance of antifracture efficacy over 10 years with strontium ranelate in postmenopausal osteoporosis. Osteoporos Int. 2012;23(3):1115-22.

58. Nielsen SP, Slosman D, Sørensen $\mathrm{OH}$, Basse-Cathalinat B, De Cassin $\mathrm{P}$, Roux $\mathrm{C}$, et al. Influence of strontium on bone mineral density and bone mineral content measurements by dual X-ray absorptiometry. J Clin Densitom. 1999;2(4):371-9.

59. Langdahl B, Binkley N, Bone H, Gilchrist N, Resch $H$, Rodriguez Portales $\mathrm{J}$, et al. Odanacatib in the treatment of postmenopausal women with low bone mineral density: five years of continued therapy in a phase 2 study. J Bone Miner Res. 2012;27(11):2251-8. 